\title{
Anti-oxidant and Anti-inflammatory Effects of Sinapic Acid in UVB Irradiation-Damaged HaCaT Keratinocytes
}

\author{
Kye Hwa Lim ${ }^{1}$, Jung-Eun $\mathrm{Ku}^{2}$, Sung-Ja Rhie ${ }^{3}$, Ji Young Ryu ${ }^{3}$, Seunghee Bae ${ }^{4}$, Young-Sam Kim ${ }^{5 *}$ \\ ${ }^{1}$ Department of Beauty Care, Sangji Youngseo College, Wonju-si, Gangwon-do, Korea \\ ${ }^{2}$ Department of Cosmetology, Kyung-In Women's University, Incheon, Korea \\ ${ }^{3}$ Department of Beauty Care Design, Halla University, Wonju-si, Gangwon-do, Korea \\ ${ }^{4}$ Research Institute for Molecular-Targeted Drugs, Department of Cosmetics Engineering, Konkuk University, Seoul, Korea \\ ${ }^{5}$ Department of Image Industry, Graduate School of Engineering, Konkuk University, Seoul, Korea
}

\begin{abstract}
"Corresponding author: Young-Sam Kim, Department of Image Industry, Graduate School of Engineering, Konkuk University, 120 Neungdong-ro, Gwangjin-gu, Seoul 05029, Korea

Tel.: +82 24503595

Email: gracehelen@konkuk.ac.kr
\end{abstract}

Received August 22, 2017

Revised September 1, 2017

Accepted September 18, 2017

Published December 30, 2017

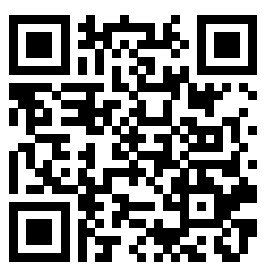

\begin{abstract}
Purpose: The purpose of the present study was to explore the possibility of using sinapic acid as a skin anti-aging cosmetic by demonstrating its antioxidant and anti-inflammatory effects in keratinocytes damaged by ultraviolet (UV) irradiation. Methods: The effects of sinapic acid against oxidative stress were examined in a UVB-induced aging model of human keratinocyte HaCaT cells. The water-soluble tetrazolium salt (WST-1) assay was employed to examine protective effects against UVB. Changes in the concentration of reactive oxygen species (ROS) produced by UVB were measured using 2',7'-dichlorofluorescin diacetate (DCF-DA). Expression of genes associated with anti-oxidant and anti-inflammatory effects were confirmed using quantitative real-time polymerase chain reaction (qRT-PCR). Results: Sinapic acid protected cells from UVB-induced cytotoxicity and reduced ROS produced by UVB irradiation. Expression of genes associated with antioxidant effects including, superoxide dismutase 1 (SOD1), catalase (CAT), glutathione peroxidase 1 (GPX1), nuclear factor (erythroid-derived 2)-like 2 (NRF2), and heme oxygenase 1 (HO1), increased and lipid peroxidation decreased in a dose-dependent manner. The expression of cyclooxygenase 2 (COX2), interleukin 6 (IL6), and interleukin 8 (IL8) genes, which are associated with inflammation, also decreased in a dose-dependent manner. Conclusion: These results suggest that sinapic acid has potential as an anti-aging cosmetic ingredient with anti-oxidant, anti-inflammatory properties against UVB irradiation.
\end{abstract}

Keywords: Sinapic acid, Anti-oxidant, Anti-inflammation, UVB, HaCaT

\section{Introduction}

피부는 외부로부터 표피, 진피, 피하층의 독특한 3 개 층으로 구 성되어 있으며, 그 중 피부의 최외측에 존재하는 표피층은 장벽 기 능을 수행하는 일차적 방어막이며 대사상 활동성인 중층 편평 각 화 상피(stratified squamous epithelium)로서 주로 각질형성세포 (keratinocyte)로 구성되어 있다(Lee et al., 2001). 이러한 피부는 외 부환경에 항상 노출되어 있어 물리적 자극, 자외선, 열, 다양한 오염 등에 영향 받기 쉽다. 특히 일상의 대사과정 중 발생되는 활성산소 종(reactive oxygen species, ROS; Lee et al., 2012)과 UV에 의해 발
생하는 ROS (Kulms et al., 2002)에 의한 산화적 스트레스(oxidative stress)는 피부노화의 주된 원인으로 작용된다(Kujoth et al., 2005).

ROS의 종류로는 superoxide anion $\left(\mathrm{O}_{2}^{-}\right)$, hydrogen peroxide $\left(\mathrm{H}_{2} \mathrm{O}_{2}\right)$, hydroxyl radical $(\mathrm{OH} \bullet)$, singlet oxygen $\left({ }^{1} \mathrm{O}_{2}\right)$ 등이 대표 적이다(Thannickal \& Fanburg, 2000). 이러한 ROS로 인한 산화 적 스트레스로 인해 야기되는 산화물질의 불균형 및 산화 억제 기 능에 대응하기 위하여 체내에는 이를 방어하는 SOD, CAT, GPX, glutathione reductase (GR), HO1 등의 효소가 존재한다(Jakus, 2000).

산화적 스트레스 환경은 다양한 세포보호 유전자들의 발현을 유 
도하는 생리적 반응을 유발하게 한다. NRF2는 핵전사인자로서 발 암성물질, 독성물질, 산화적 손상의 노출에 반응하여 활성화되고, 항산화반응요소(antioxidant response element, $\mathrm{ARE}$ )의 결합을 통 한 해독 및 Phase II 항산화 관련 효소의 발현을 촉진하여 세포를 보호하는 역할을 수행한다(Kensler et al., 2007). NRF2는 정상적인 조건에서는 Kelch-like ECH-associated protein 1 (KEAP1)에 결합 되어 세포질 내에 존재하나 ROS와 같은 자극을 받게 되면 KEAP1으 로부터 유리되어 핵 내로 이동하여 핵 내에 존재하는 Maf 단백질과 결합하여 dimer를 이루고 항산화 효소의 promoter 부위에 존재하는 $\mathrm{ARE}$ 와 결합함으로써 $\mathrm{GR}, \mathrm{HO} 1, \mathrm{NAD}(\mathrm{P}) \mathrm{H}$ quinone dehydrogenase 1 (NQO1), gamma-glutamate cysteine ligase ( $\gamma \mathrm{GCL}$ ), glutathione $\mathrm{S}$-transferase (GST)와 같은 항산화 효소들의 발현을 증가시킨다 (Kang et al., 2005; Lee \& Surh, 2005; Lee et al., 2017).

$\mathrm{ROS}$ 에 의해 생성되는 산화적 스트레스와 미토콘드리아의 산소 대사산물에 의한 신호전달과 조직의 파괴는 nuclear factor kappa $\mathrm{B}(\mathrm{NF \kappa B})$ 의 염증 매개 유전자를 발현시켜 체내 염증반응을 유발 하게 한다. $\mathrm{NFkB}$ 는 세포 내에서 염증 반응을 조절하는 대표적인 전사조절 인자이다. 세포질에서 $\mathrm{NF \kappa}$ 는 활성화를 억제하는 단백 질 inhibitor of kappa B (IKB)와 함께 존재한다. UV나 ROS와 같 은 다양한 자극에 의해서 IKB kinase (IKK)에 의해 인산화되어 NF $\kappa \mathrm{B}$ 로부터 $\mathrm{I} \kappa \mathrm{B}$ 의 결합이 분해되면서 떨어지게 된다. $\mathrm{I} \kappa \mathrm{B}$ 로부터 자 유로워진 $\mathrm{NF \kappa B}$ 는 핵 속으로 이동하며 핵 속에서 $\kappa \mathrm{B}$ binding site 에 결합하여 inducible nitric oxide synthase (iNOS), COX2, tumor necrosis factor-alpha (TNF $\alpha$ ), interferon gamma ( $\mathrm{FN} \gamma), \mathrm{L} 6$, L8, interleukin 1 beta (11), 등의 발현을 유도한다(Baeuerle, 1998; Longley et al., 1988; Takeda et al., 2003).

Sinapic acid는 주로 향신료, 베리류의 과일, 감귤류, 채소, 곡물, 오일 씨드(oil seed)등의 다양한 식물에서 발견되는 페놀화합물이다 (Sawa et al., 1999; Shahidi \& Naczk, 2003). Sinapic acid는 항암 (Balaji et al., 2014), 고혈당 완화(Cherng et al., 2013), 신경세포보 호(Zare et al., 2015), 항혈전(Kim et al., 2016), 항불안(Yoon et al., 2007), 간세포보호(Shin et al., 2013) 등의 효과가 보고되어 있으 며, 인간 모낭 모유두 세포(human hair follicle dermal papilla cells, $\mathrm{HFDPC})$ 의 모발에서 성장 인자의 발현을 유도하여 모발 성장을 유 도함으로써 탈모 치료를 위한 잠재적 화합물로서의 가능성도 제시 되었다(Woo et al., 2017). 본 연구에서는 sinapic acid 처리 시 UVB 에 의해 발생하는 산화적 스트레스에 인간각질형성세포( $\mathrm{HaCaT})$ 에 서 항산화제 활성을 증가시킬 수 있는지를 알아보기 위하여 세포 내 ROS 제거를 하는 대표적인 항산화 효소인 SOD1, GPx1, CAT, $\mathrm{NRF2}$ 그리고 $\mathrm{HO} 1$ 유전자의 발현변화를 확인하여 항산화 효능을 확인하고 염증관련 유전자인 $C O X 2, \amalg 6$ 및 $L 8 \mathrm{mRNA}$ 발현의 변화 를 확인하여 피부노화 예방에 도움을 줄 수 있는 기능성을 가진 화 장품 원료로서의 가능성을 제시하고자 한다.

\section{Methods}

\section{1. 세포배양}

본 연구에서 사용한 인간각질형성세포주인 $\mathrm{HaCaT}$ keratinocytes는 American Type Culture Collection (ATCC; $\mathrm{USA}$ )에서 구매하여 사용하였고, $\mathrm{HaCaT}$ 세포주의 배양은 Dulbecco's modified Eagles medium (DMEM; HyClone ${ }^{\mathrm{TM}}$, GE Healthcare Life Sciences, UK)에 10\% fetal bovine serum (FBS; HyClone $\left.^{\mathrm{TM}}\right)$ 과 $1 \%$ penicillin $(100 \mathrm{IU} / \mathrm{mL}) /$ streptomycin $(100 \mu$ $\mathrm{g} / \mathrm{mL}$ ) (Invitrogen ${ }^{\mathrm{TM}}$, Thermo Fisher Scientific, USA)을 함유한 배지를 사용하였고, 세포배양기 내의 조건은 $37^{\circ} \mathrm{C}, 5 \% \mathrm{CO}_{2}$ 를 유 지시키며 배양하였다.

\section{2. 시료처리 및 자외선 조사}

Sinapic acid는 순수정제 $>90 \%$ )된 분말형태로 Sigma-Aldrich (USA)에서 구매하였으며, 실험에 사용할 때에는 dimethyl sulfoxide (DMSO; Sigma-Aldrich)에 적정 농도로 용해하여서 사용하였다. 세포배양접시에 HaCaT $\left(1 \times 10^{6}\right.$ cells/well)을 $24 \mathrm{~h}$ 배양한 후 적정 농도의 sinapic acid를 배지에 첨가하여 $6 \mathrm{~h}$ 동안 전 처리하였으며, 세포에 UV-B lamp (UVP, USA)를 사용하여 $\mathrm{UVB}$ 를 조사하였다. UVB 조사 전 우선 세포배양접시의 배지 제 거를 위해 pH7.4의 phosphate-buffered saline (PBS; Thermo Fisher Scientific)로 2회 세척을 하였으며 세포의 건조를 막기 위 해 $\mathrm{PBS}$ 를 넣은 후 세포배양접시의 뚜껑을 열고 $\mathrm{UVB}$ 를 조사하 였다. UVB 파장의 측정은 Fiber Optic Spectrometer System USB2000 (Ocean Optics, USA)을 사용하였으며, UVB 조사 후에 $\mathrm{PBS}$ 를 제거하였고 새로운 배양배지를 첨가하여 $24 \mathrm{~h}$ 배양기에서 추가 배양한 후 실험에 사용하였다.

\section{3. 세포 생존율 측정}

세포 생존율의 실험방법으로는 water-soluble tetrazolium salt (WST-1) assay 원리를 이용하였다. 96-well plate에 HaCaT $\left(3 \times 10^{3}\right.$ cells/well)을 $100 \mu \mathrm{L}$ 씩 접종하여 $24 \mathrm{~h}$ 을 배양한 후, $\mathrm{HaCaT}$ 에 sinapic acid를 5, 10, 20, 40, $80 \mu \mathrm{M}$ 로 처리하고 $24 \mathrm{~h}$ 추가 배양한 후 세포 생존율을 측정하였으며, 같은 조건으로 추 가 배양한 다른 배양접시의 $\mathrm{HaCaT}$ 에는 sinapic acid를 각각 10 , $20,40 \mu \mathrm{M}$ 로 처리하고, $40 \mathrm{~mJ} / \mathrm{cm}^{2} \mathrm{UVB}$ 조사 후 $24 \mathrm{~h}$ 동안 추 가 배양하였다. 배양된 세포에 EZ-Cytox cell viability assay kit reagent (iTSBiO, Korea)을 $10 \mu \mathrm{L}$ 첨가하여 $1 \mathrm{~h}$ 후에 microplate reader (Bio-Rad Laboratories, USA)로 $490 \mathrm{~nm}$ 에서 흡광도를 측정하였다.

\section{4. 세포 내 ROS 정량 분석}

$\mathrm{HaCaT}\left(2 \times 10^{5}\right.$ cells/well)을 $60 \mathrm{~mm}$ 배양접시에 접종하여 

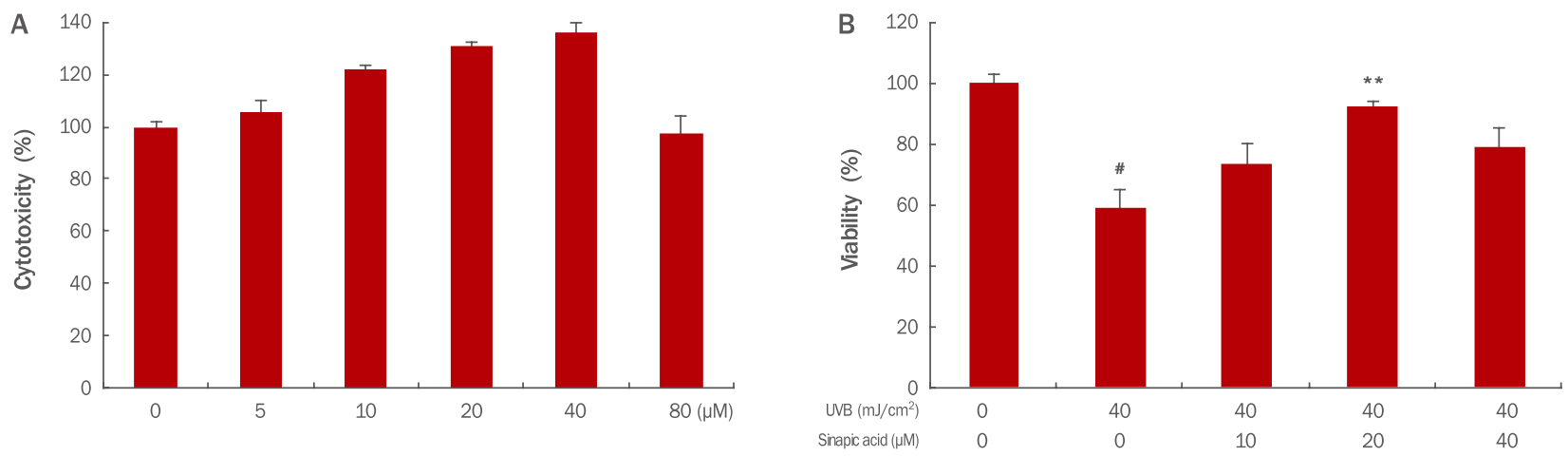

Figure 1. Cell survival analysis of UVB-irradiated and sinapic acid treated HaCaT cells.

HaCaT cells were inoculated into 96-well plate at a $3 \times 10^{3}$ cells/well and incubated for $24 \mathrm{~h}$. (A) Sinapic acid was added at various concentrations and cells were cultured for $24 \mathrm{~h}$. The survival rate did not decrease compared with the control group until sinapic acid treatment at $40 \mu \mathrm{M}$. (B) The cells were pretreated with sinapic acid at 10, 20, and $40 \mu \mathrm{M}$ for $6 \mathrm{~h}$ and irradiated with $40 \mathrm{~mJ} / \mathrm{cm}^{2}$ of UVB. After $24 \mathrm{~h}$ of incubation, cell viability was determined using the WST-1 assay. Cell survival was restored in a dose-dependent manner. The results show the mean and standard deviation for three independent experiments $\left({ }^{* *} p<0.01\right.$; $\left.{ }^{*} p<0.05\right)$. UVB, ultraviolet B; WST-1, watersoluble tetrazolium salt.

Table 1. List of primers used in this study

\begin{tabular}{lll}
\hline Gene & Forward primer $\left(5^{\prime} \rightarrow 3^{\prime}\right)$ & Reverse primer $\left(5^{\prime} \rightarrow 3^{\prime}\right)$ \\
$\beta$-actin & GGATTCCTATGTGGGCGACGA & CGCTCGGTGAGGATCTTCATG \\
SOD1 & GGGAGATGGCCCAACTACTG 1 & CCAGTTGACATCGAACCGTT \\
CAT & TTCCCGTGCAACCAGTTTG & GGACGTACTTGAGGGAATTCAGA \\
$N R F 2$ & ATGGTCCATGCTCTCAAACC & CAGGTCATCCAATAGGAAGG \\
HO1 & TACTCCCAGGTTGCCCACA & CATCTACAAACGGGAATGTCTGC \\
COX2 & GCCTGCTAGCCTGGTTCAAG & AGCGGTGTCTGGGATGAACTA \\
$I L 6$ & CGCGGATCCGCGGTGAGAACCGTTTAC & GCGAGGAAGCGGAAGAGTCTAGAGTCGACC \\
IL8 & TAACAGTTCCTGCATGGGCGGC & AGGACAGGCACAAACACGCACC \\
\hline
\end{tabular}

$\beta$-actin, beta-actin; SOD1, superoxide dismutase 1; GPX1, glutathione peroxidase 1; CAT, catalase; NRF2, nuclear factor (erythroid-derived 2)like 2; HO1, heme oxygenase 1; COX2, cyclooxygenase 2; IL6, interleukin 6; IL8, interleukin 8.

$24 \mathrm{~h}$ 배양 후, 세포에 sinapic acid를 처리한 다음 $24 \mathrm{~h}$ 을 추가로 배양하였다. 세포 내 ROS를 측정하기 위해 DCF-DA (SigmaAldrich)를 $10 \mu \mathrm{M}$ 를 첨가하여 $30 \mathrm{~min}$ 배양 후에 세포를 수확하 였다. PBS를 첨가하여 세포를 풀어준 다음 Flow Cytometer (BD Biosciences, USA)를 이용하여 ROS의 변화량을 측정하였다. Sinapic acid의 ROS 제거 효능을 검증하기 위하여 양성대조군으 로 ROS scavenger 역할을 하는 N-acetyl-L-cysteine (NAC; Calbiochem, USA)을 사용하였으며, sinapic acid와 동일한 방식 으로 처리 후 측정하였다.

\section{Quantitative real-time polymerase chain reaction (qRT- PCR)}

세포배양으로 얻은 세포를 TRIzol reagent (Invitrogen ${ }^{\mathrm{TM}}$ )를 이용하여 추출하였다. 추출된 RNA는 Nanodrop (Maestrogen,
USA)을 이용하여 $260 / 280 \mathrm{~nm}$ ratio 1.8 이상 순도의 RNA 만을 실험에 사용하였다. $\mathrm{cDNA}$ 는 $\mathrm{PCR}$ tube에 $1 \mu \mathrm{g} \mathrm{RNA}$, 0.5 ng oligo dT18, diethyl pyrocarbonate (DEPC; Biopure, Canada) water를 total $10 \mu \mathrm{L}$ 로 제조한 후 $70^{\circ} \mathrm{C}$ 에서 $10 \mathrm{~min}$ 처 리하여 RNA 변성을 유도하여 M-MLV reverse transcriptase (Enzynomics, Korea)를 이용하여 $37^{\circ} \mathrm{C}$ 에서 $1 \mathrm{~h}$ 반응시켜 cDNA 를 합성하여 사용하였다.

qRT-PCR은 PCR tube에 5x HOT FIREPol ${ }^{\circledR}$ EvaGreen ${ }^{\circledR}$ qPCR Supermix (Solis Biodyne, Estonia)을 사용하여 반응액을 제조하였다. LineGene K (Hangzhou Bioer Technology, China) 를 사용하여 $\mathrm{PCR}$ 을 진행하였으며 PCR의 유효성은 melting curve로 검증하였다. 각 유전자의 발현은 $\beta$-actin (beta-actin) 의 발현을 표준화하여 비교 분석하였다. 실험에 사용된 primer는 Table 1과 같다. 


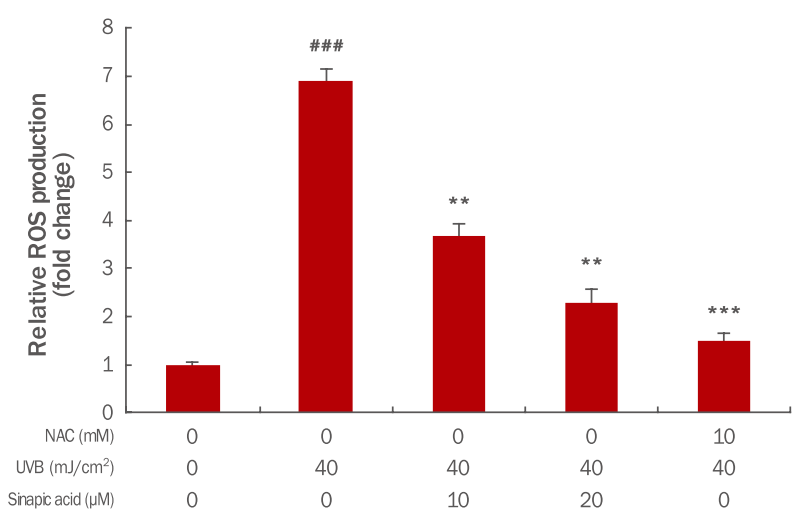

Figure 2. ROS scavenging in UVB-irradiated and sinapic acid treated HaCaT cells.

Sinapic acid was added for $6 \mathrm{~h}$, and cells were UVB-irradiated and cultured for $24 \mathrm{~h}$. DCF-DA (10 $\mu \mathrm{M})$ was added and the cells were harvested after incubating for $30 \mathrm{~min}$. After the addition of PBS, the amount of ROS change was measured using flow cytometry. Compared with the control group that was not irradiated with UVB, ROS decreased in a dose-dependent manner when pretreated with sinapic acid. In addition, increased anti-oxidative effects were obtained when compared with $10 \mathrm{mM} \mathrm{NAC}$ control group. The results show the mean and standard deviation for three independent experiments $\left({ }^{* * *} p<0.001 ;{ }^{* *} p<0.01\right.$; $\left.{ }^{\# \#} p<0.001\right)$. ROS, reactive oxygen species; NAC, N-acetyl-L-cysteine; UVB, ultraviolet B; DCF-DA, 2',7'-dichlorofluorescin diacetate; PBS, phosphate buffered saline.

\section{Lipid peroxidation 변화량 분석}

Lipid Peroxidation Assay Kit (Abcam, UK)를 사용하여 제공 된 실험방법에 따라 실험을 수행하였다. Malondialdehyde (MDA) lysis buffer로 cell을 ice에서 균질화시키고, 원심분리 $(1300 \times \mathrm{g}$, $10 \mathrm{~min}$ )하여 $200 \mu \mathrm{L}$ 상층액만을 분리하고, kit에 있는 $600 \mu \mathrm{L}$ 의 thiobarbituric acid (TBA) solution을 각 test tube에 넣고, $95^{\circ} \mathrm{C}$ 에서 $1 \mathrm{~h}$, ice에서 $10 \mathrm{~min}$ 식힌 뒤, 96-well plate에 $200 \mu \mathrm{L}$ 씩 분 주하여 $586 \mathrm{~nm}$ 에서 microplate reader로 흡광도를 측정하였다.

\section{7. 통계분석}

본 연구에서의 모든 실험은 동일한 조건하에서 독립적으로 3 회 이상을 실시하여 실험 결과를 얻었으며, 실험의 결과는 평균 \pm 표준편차(mean \pm standard deviation, $\mathrm{M} \pm \mathrm{SD}$ )로 나타내었다. 각 실험에 관하여 Student's $t$-test를 이용하여 모든 실험 결과의 $p$-value 값이 0.05 이하인 경우에 통계적으로 유의하다고 분석하 였다.

\section{Results and Discussion}

\section{Sinapic acid의 세포 생존율 분석}

Sinapic acid가 HaCaT 세포에 미치는 세포독성을 확인하기 위해 WST-1 assay를 이용하여 세포 생존율을 측정하였다. HaCaT 세포 에서 sinapic acid의 독성을 확인한 결과 sinapic acid를 처리하지 않 은 대조군의 세포 생존율(100\%)을 기준으로 하였을 때, sinapic acid 를 $5,10,20,40,80 \mu \mathrm{M}$ 처리 시 $105 \%, 121 \%, 130 \%, 136 \%, 97 \%$ 의 생존율을 보여 $40 \mu \mathrm{M}$ 까지는 생존율이 감소하지 않았으며, sinapic acid $80 \mu \mathrm{M}$ 처리 시 세포 생존율이 다소 감소하는 것으로 나타났 다(Figure $1 \mathrm{~A}$ ). 또한, UVB에 의해 손상된 $\mathrm{HaCaT}$ 세포에서 sinapic acid의 세포보호 효능을 알아보기 위해 세포 생존율의 변화를 측정 하였다. 그 결과 UVB만 조사된 대조군의 세포 생존율(59\%)에 비 해 sinapic acid을 $10 \mu \mathrm{M}$ 전 처리한 경우 $73 \%, 20 \mu \mathrm{M}$ 에서 $92 \%$ 의 세 포 생존율을 보여 sinapic acid에 의해 농도 의존적으로 세포 생존 율이 회복되는 것이 확인되었다. 단 $40 \mu \mathrm{M}$ 에서 세포 생존율이 $79 \%$ 로 감소하여 향후 실험은 $10,20 \mu \mathrm{M}$ 농도를 사용하기로 결정하였다 (Figure 1B).

\section{Sinapic acid의 ROS 제거 효능 분석}

본 실험에서는 sinapic acid가 HaCaT 세포 내 ROS를 제거하는 능력을 확인하기 위해서 DCF-DA assay를 이용하였다. HaCaT에 sinapic acid를 처리하지 않고 UVB를 조사한 대조군은 ROS량이 6.9 로 증가하였으나 sinapic acid를 $10 \mu \mathrm{M}$ 전 처리 시 $3.6,20 \mu \mathrm{M}$ 전 처 리 시 2.2 로 농도 의존적으로 감소하였다. 양성대조군으로 사용한 ROS scavenger 역할을 하는 NAC의 $10 \mathrm{mM}$ 의 1.5 와 비교하였을 때 보다 뛰어난 항산화 효과가 있는 것을 확인하였다(Figure 2).

\section{Sinapic acid의 항산화 유전자 발현분석}

체내의 여러 대사반응의 결과로 생성되는 $\mathrm{O}_{2}^{-}, \mathrm{H}_{2} \mathrm{O}_{2}$ 등의 과산화 물은 세포 안의 DNA, 단백질, 지질 등의 고분자물질과 반응하여 다 른 ROS를 형성하는 연쇄전파과정을 일으킨다(Niki et al., 1991). 이에 대응하여 인체 내 항산화 물질들은 산화적 스트레스로 인한 손 상으로부터 신체를 보호하며 상호작용에 의하여 각각의 항산화 기 능을 상승시켜줌으로써 산화적 스트레스로부터 인체를 방어하는 역 할을 하는 것으로 보고되고 있다(Frei et al., 1990, Schmidt, 1991). 본 연구에서는 UVB로 인해 증가된 산화적 스트레스로 인해 야기되 는 산화물질의 불균형 및 산화 억제 기능을 위해서 체내에서 생성해 내는 여러 항산화 물질들의 변화량을 확인하기 위하여 $\mathrm{qRT}-\mathrm{PCR}$ 을 수행하였다. HaCaT에서 UVB로 인해 SOD1, GPX1, CAT, NRF2 $\mathrm{mRNA}$ 의 발현량이 감소하였으나 sinapic acid를 $10,20 \mu \mathrm{M}$ 로 전처 리 시 발현량이 $S O D 1$ 은 0.75 으로 감소하였으나 $1.01,1.37$ 로 농도 의존적으로 증가하였으며, $G P X 1$ 은 0.31에서 0.90, 2.46로, $C A T$ 는 0.23 에서 $0.77,0.97$ 으로, NRF2는 0.46 에서 $0.75,0.99$ 로 농도 의 존적으로 증가되는 것을 확인할 수 있었다. $H O 1 \mathrm{mRNA}$ 의 발현량은 $\mathrm{UVB}$ 조사시 1.77 으로 증가하였으며 sinapic acid를 전처리 시 2.51, 3.72 로 농도 의존적으로 발현량이 더욱 증가되어 더 많은 항산화 효 

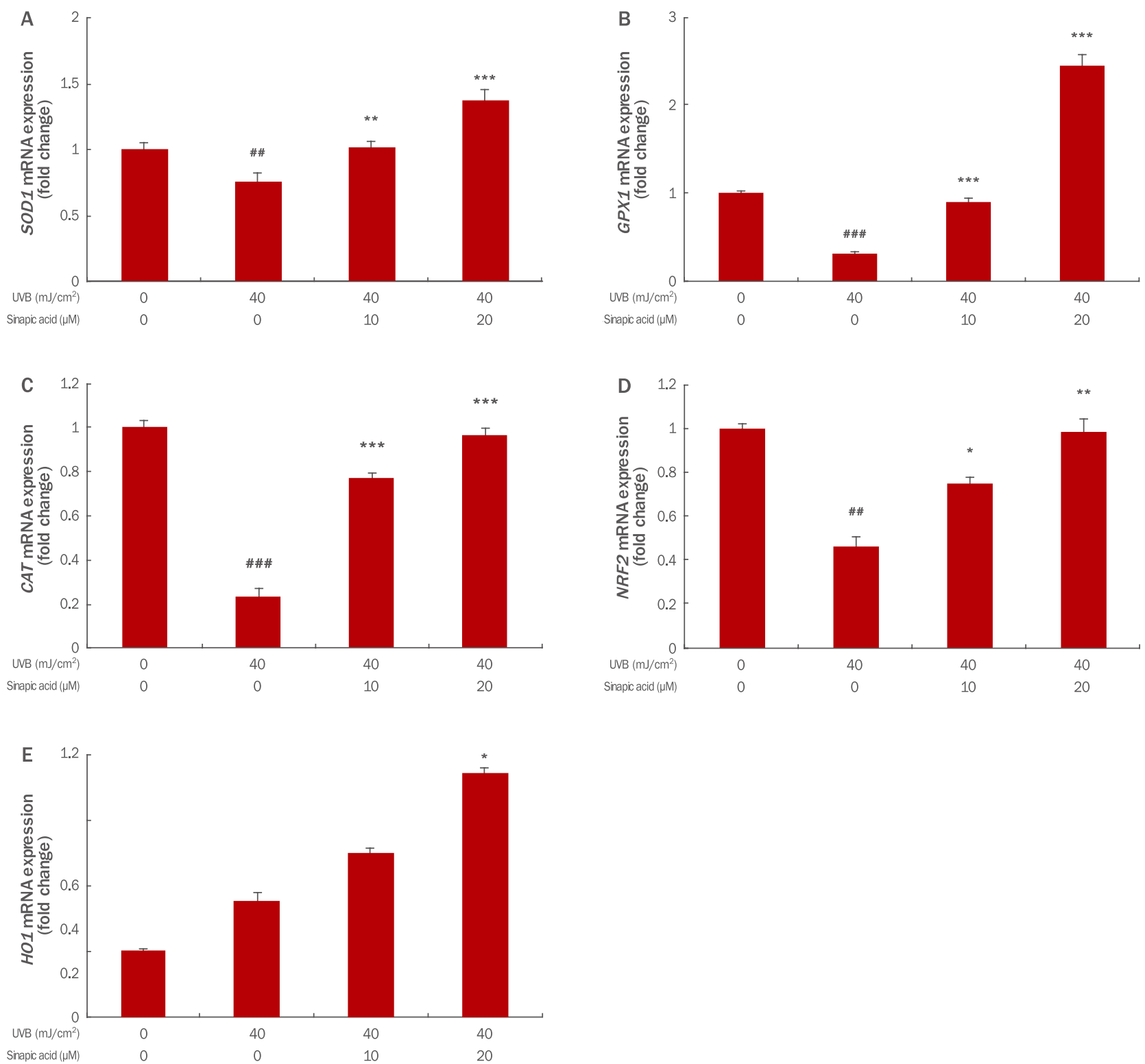

Figure 3. Anti-oxidant gene expression analysis of HaCaT cells treated with UVB irradiation and sinapic acid.

The indicated concentrations of sinapic acid were added to the culture medium for $6 \mathrm{~h}$ then cells were irradiated with $40 \mathrm{~mJ} / \mathrm{cm}^{2}$. After further incubation for $24 \mathrm{~h}$, changes in anti-oxidant gene expression were analyzed using qRT-PCR. (A-D) The expression of SOD1, GPX1, CAT, and NRF2 mRNA increased in a dose-dependent manner when cells were pretreated with sinapic acid before UVB irradiation. (E) The gene expression of HO1 mRNA was also increased in a concentration-dependent manner when compared with the control group. The results show the mean and standard deviation for three independent experiments $\left({ }^{*} p<0.05 ;{ }^{* *} p<0.01 ;{ }^{* * *} p<0.001\right.$; ${ }^{\# \#} p<0.01$; $\# \#$ <0.001). UVB, ultraviolet B; qRT-PCR, quantitative real-time polymerase chain reaction; SOD1, superoxide dismutase 1; GPX1, glutathione peroxidase 1; CAT, catalase; NRF2, nuclear factor (erythroid-derived 2)-like 2; HO1, heme oxygenase 1.

능을 나타내고 있음을 확인하였다(Figure 3). 이것은 sinapic acid가 산화적 스트레스로부터 세포를 보호할 뿐 아니라 세포 내의 환원력 을 유지하는데 효과가 있을 것으로 생각된다.

\section{Sinapic acid의 lipid peroxidation 변화량 분석}

$\mathrm{ROS}$ 로 인한 산화적 스트레스는 단백질이나 DNA를 산화시켜서
구조적 변화를 일으키게 하고, 세포막의 지방산을 산화시켜 지질 과 산화물인 $\mathrm{MDA}$ 의 함량을 증가시키게 된다. 이러한 $\mathrm{MDA}$ 의 증가는 세포의 산화적 손상을 일으켜 세포의 기능을 저하시킴으로써 암과 같은 여러 가지 만성질환을 유발하게 한다(Gloire et al., 2006). 그러 므로 본 연구에서는 MDA assay를 이용하여 지질산화의 최종산물을 측정하였다. Sinapic acid와 UVB 모두 처리하지 않은 대조군의 level 


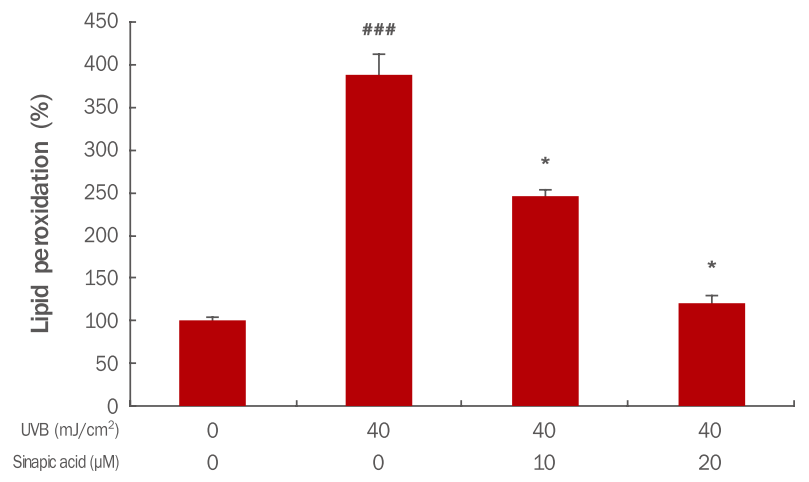

Figure 4. Analysis of changes in lipid peroxidation of HaCaT cells treated with UVB and sinapic acid.

HaCaT cells were inoculated into 6 -well plates at $1 \times 10^{6}$ cells/ well and were further pretreated with sinapic acid. The cells were UVB irradiated and cultured for $24 \mathrm{~h}$. MDA assay was performed to determine the degree of lipid peroxidation in cells damaged caused by UVB irradiation. When cells were pretreated with sinapic acid lipid peroxidation decreased in a dose-dependent manner. The results show the mean and standard deviation for three

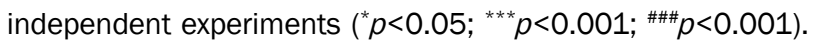
UVB, ultraviolet B; MDA, malondialdehyde.

을 $100 \%$ 로 보았을 때 UVB만 처리시 $388 \%$ 로 증가하였으며, sinapic acid 전 처리 시 농도 의존적으로 감소함을 확인할 수 있었다(Figure 4). 이러한 결과는 sinapic acid가 UVB로부터 세포의 지질산화물의 생성을 감소시켜 세포 내 항산화 효과가 있을 것으로 사료된다.

\section{Sinapic acid의 항염증 유전자 발현분석}

체내의 산화환원의 불균형은 $\mathrm{NFKB}$ 의 활성화를 일으키고 활성화 된 NFkB는 $i N O S, C O X 2, T N F \alpha, I L 6, I L 8, I L 1 \beta$ 등과 같이 여러 노화와 관련된 유전자 및 사이토카인(cytokine)을 발현시키고 이로 인해 염증반응이 유발되며 노화로 진행된다. 본 연구에서는 sinapic acid가 이러한 $C O X 2, \amalg 6, \amalg 8$ 의 발현에 미치는 영향을 확인해 보 았다. UVB로 유도된 HaCaT에 sinapic acid를 전 처리한 후, COX2, $\mathrm{IL} 6, \mathrm{~L} 8$ 유전자 발현을 확인한 결과 UVB만 처리시 각각 9.31 , $6.50,3.62$ 으로 증가되었으나 sinapic acid를 $10,20 \mu \mathrm{M}$ 으로 전처리 시 COX2는 4.42, 2.27으로, 166 은 4.77, 2.00으로, $1 L 8$ 은 2.23, 1.65 로 농도 의존적으로 발현량이 감소됨을 확인할 수 있었다(Figure 5). 이를 통하여 sinapic acid가 염증을 억제하는 효과가 있을 것으로 사료된다.

\section{Conclusion}

ROS는 산소원자를 포함한 짝지어지지 않은 불안정상태로 화 학적으로 반응성이 매우 높다. 세포신호와 항상성에 중요한 역할
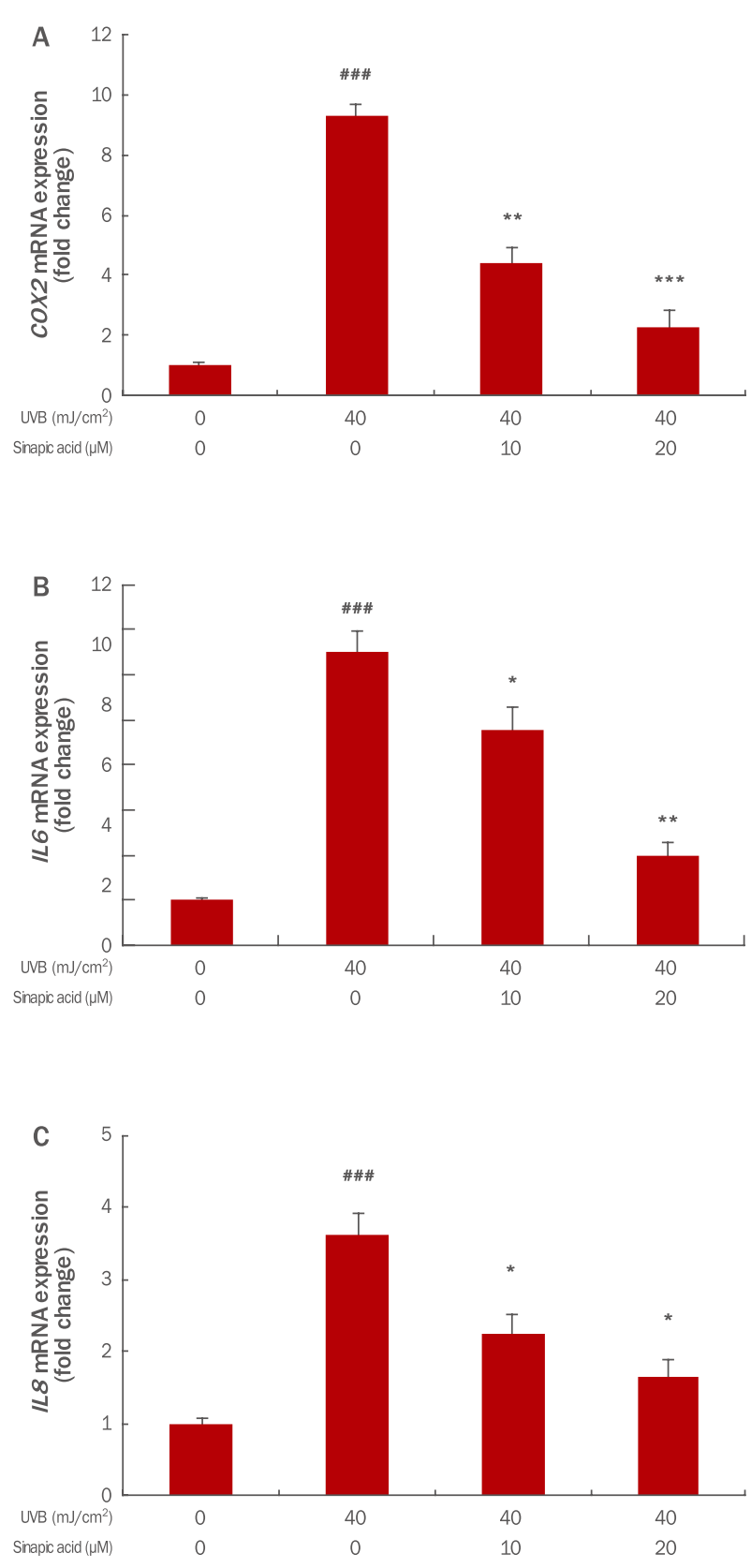

Figure 5. Analysis of inflammatory gene expression in UVB irradiated HaCaT cells pretreated with sinapic acid.

The indicated concentrations of sinapic acid were added to the culture medium for $6 \mathrm{~h}$, and the cells were irradiated with 40 $\mathrm{mJ} / \mathrm{cm}^{2}$ of UVB, After further incubation for $24 \mathrm{~h}$ changes in inflammatory gene expression were examined using qRT-PCR. (A-C) The expressions of COX2, IL6, and IL8 mRNA, which was increased by UVB irradiation, were found to decreased in a dosedependent manner when the cells were pretreated with sinapic acid. The results show the mean and standard deviation for three independent experiments $\left({ }^{*} p<0.05 ;{ }^{* *} p<0.01\right.$; ${ }^{* * *} p<0.001$;

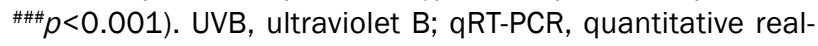
time polymerase chain reaction; $\operatorname{COX} 2$, cyclooxygenase $2 ; I L 6$, interleukin 6; IL8, interleukin 8. 
을 한다고 알려져 있지만 산화적 스트레스로 인해 세포의 구조가 손상될 수도 있다. 이러한 산화적 스트레스는 세포 내 DNA, 지질, 단백질 등의 변형 및 손상과 세포괴사(necrosis) 또는 세포자멸사 (apoptosis) 등을 초래하여 노화뿐만이 아닌 질병을 일으키는데도 관여한다(Sagara et al., 1998). 본 연구에서 이러한 세포에 손상을 주는 ROS를 제거하는 sinapic acid의 효능을 확인하기 위하여 항산 화 표준물질로 사용되는 NAC과 함께 $\mathrm{DCF}-\mathrm{DA}$ 를 이용하여 비교 실 험을 한 결과 NAC보다도 더 많은 항산화 효능이 있음을 확인할 수 있었다. 또한 체내에서 생성해내는 여러 항산화 물질들의 변화량을 확인하기 위하여 qRT-PCR을 확인한 결과 $\mathrm{HaCaT}$ 에서 UVB로 인 해 발현량이 감소되었던 $S O D 1, G P X 1, C A T, N R F 2 \mathrm{mRNA}$ 의 발 현량을 sinapic acid에 의해 농도 의존적으로 발현량이 증가하였으 며, $H O 1 \mathrm{mRNA}$ 의 발현량 또한 대조군과 비교하여 농도 의존적으 로 증가하였다. 산화적 스트레스를 측정하는 지표로 사용되는 lipid peroxidation의 변화량 또한 UVB로 인하여 증가하였으나 sinapic $\mathrm{acid}$ 를 전 처리 시 농도 의존적으로 감소하였다. 항염증과 관련하여 sinapic acid의 농도가 증가할수록 염증반응전사인자인 COX2와 염 증진단 표지자인 $\amalg 6, \amalg 8 \mathrm{mRNA}$ 발현량이 감소하는 것을 확인하 였다. 이는 염증발생을 억제시키는 효능이 있을 것으로 사료된다. 이렇듯 sinapic acid는 유전자 레벨에서부터 조절하여 다각적인 방 법으로 항산화 효능 및 항염증 효능을 나타내고 있다는 것을 확인할 수 있었다.

본 연구는 세포효능을 위주로 진행되었으며 화장품 소재로서 활 용하기 위해서는 화장품의 기본적인 성분이 갖는 화학적 특성과 sinapic acid의 생화학적 특성이 잘 배합되고 조합되어 피부에 적용 하였을 때 목적하는 효과를 나타낼 가능성이 있는지를 평가하는 향 후 연구가 추가적으로 진행되어야 할 것으로 생각된다.

This work is part of the Kye Hwa Lim's Ph.D. thesis at the Konkuk University, Seoul, Korea.

\section{Acknowledgements}

본 논문은 보건복지부 보건의료연구개발사업의 지원(과제번호: $\mathrm{HN} 13 \mathrm{C0080)}$ 에 의한 것이며, 이에 감사드립니다.

\section{References}

Baeuerle PA. Pro-inflammatory signaling: last pieces in the NFKB puzzle? Current Biology, 8: R19-R22, 1998.

Balaji C, Muthukumaran J, Nalini N. Chemopreventive effect of sinapic acid on 1,2-dimethylhydrazime-induced experimental rat colon carcinogenesis. Human \& Experimental Toxicology, 33: 1253-1268, 2014.
Cherng YG, Tsai CC, Chung HH, Lai YW, Kuo SC, Cheng JT. Antihyperglycemic action of sinapic acid in diabetic rats. Journal of Agricultural and Food Chemistry, 61: 1205312059, 2013.

Frei B, Stocker R, England L, Ames BN. Ascorbate: the most effective antioxidant in human blood plasma. Antioxidants in Therapy and Preventive Medicine, 264: 155-163, 1990.

Gloire G, Legrand-Poels S, Piette J. NF-kB activation by reactive oxygen species: fifteen years later. Biochemical Pharmacology, 72: 1493-1505, 2006.

Jakus $V$. The role of free radicals, oxidative stress and antioxidant systems in diabetic vascular disease. Bratislavské Lekárske Listy, 101: 541-551, 2000.

Kang KW, Lee SJ, Kim SG. Molecular mechanism of Nrf2 activation by oxidative stress. Antioxidants \& Redox Signaling, 7: 1664-1673, 2005.

Kensler TW, Wakabayashi N, Biswal S. Cell survival responses to environmental stresses via the Keap1-Nrf2-ARE pathway. Annual Review of Pharmacology and Toxicology, 47: 89-116, 2007.

Kim MS, Shin WC, Kang DK, Sohn HY. Anti-thrombosis activity of sinapic acid isolated from the lees of bokbunja wine. Journal of Microbiology and Biotechnology, 26: 61-65, 2016.

Kujoth GC, Hiona A, Pugh TD, Someya S, Panzer K, Wohlgemuth SE, Hofer T, Seo AY, Sullivan R, Jobling WA, et al. Mitochondrial DNA mutations, oxidative stress, and apoptosis in mammalian aging. Science, 309: 481-484, 2005.

Kulms D, Zeise E, Pöppelmann B, Schwarz T. DNA damage, death receptor activation and reactive oxygen species contribute to ultraviolet radiation-induced apoptosis in an essential and independent way. Oncogene, 21: 58445851,2002

Lee JS, Surh YJ. Nrf2 as a novel molecular target for chemoprevention. Cancer Letters, 224: 171-184, 2005.

Lee MG, Jo GH, Kim MN. Structure and function of skin. In: Dermatology. Korean society of dermatology textbook compilation committee (ed.), Ryo Moon Gak, Seoul, pp129, 2001.

Lee NK, Ku JE, Han HS. Cytoprotective and anti-inflammatory effects of 6-shogaol on human dermal fibroblasts. Asian Journal of Beauty and Cosmetology, 15: 367-376, 2017. 
Lee YR, Noh EM, Han JH, Kim JM, Hwang JK, Hwang BM, Chung EY, Kim BS, Lee SH, Lee SJ, et al. Brazilin inhibits UVB-induced MMP-1/3 expressions and secretions by suppressing the NF-kB pathway in human dermal fibroblasts. European Journal of Pharmacology, 674: 8086, 2012.

Longley BJ, Braverman IM, Edelson RL. Immunology and the skin: current concepts. Annals of the New York Academy of Sciences, 548: 225-232, 1988.

Niki E, Yamamoto Y, Komuro E, Sato K. Membrane damage due to lipid oxidation. The American Journal of Clinical Nutrition, 53: 201S-205S, 1991.

Sagara Y, Dargusch R, Chambers D, Davis J, Schubert D, Maher P. Cellular mechanisms of resistance to chronic oxidative stress. Free Radical Biology and Medicine, 24: 1375-1389, 1998.

Sawa T, Nakao M, Akaike T, Ono K, Maeda H. Alkylperoxyl radical-scavenging activity of various flavonoids and other phenolic compounds: implications for the anti-tumorpromoter effect of vegetables. Journal of Agricultural and Food Chemistry, 47: 397-402, 1999.

Schmidt K. Antioxidant vitamins and beta-carotene: effects on immunocompetence. The American Journal of Clinical Nutrition, 53: 383S-385S, 1991.
Shahidi F, Naczk M. Phenolics in food and nutraceuticals. CRC Press, Boca Raton, pp17-82, 2003.

Shin DS, Kim KW, Chung HY, Yoon S, Moon JO. Effect of sinapic acid against carbon tetrachloride-induced acute hepatic injury in rats. Archives of Pharmacal Research, 36: 626633, 2013.

Takeda K, Kaisho T, Akira S. Toll-like receptors. Annual Review of Immunology, 21: 335-376, 2003.

Thannickal VJ, Fanburg BL. Reactive oxygen species in cell signaling. American Journal of Physiology - Lung Cellular and Molecular Physiology, 279: L1005-L1028, 2000.

Woo H, Lee S, Kim S, Park D, Jung E. Effect of sinapic acid on hair growth promoting in human hair follicle dermal papilla cells via Akt activation. Archives of Dermatological Research, 309: 381-388, 2017.

Yoon BH, Jung JW, Lee JJ, Cho YW, Jang CG, Jin C, Oh TH, Ryu JH. Anxiolytic-like effects of sinapic acid in mice. Life Sciences, 81: 234-240, 2007.

Zare K, Eidi A, Roghani M, Rohani AH. The neuroprotective potential of sinapic acid in the 6-hydroxydopamineinduced hemi-parkinsonian rat. Metabolic Brain Disease, 30: 205-213, 2015. 


\section{국문초록}

\section{Sinapic acid의 인간각질형성세포에서 UVB의 손상에 대한 항산화 및 항염증 효과}

임계화 ${ }^{1}$, 구정은 ${ }^{2}$, 이승자 ${ }^{3}$, 류지영 ${ }^{3}$, 배승희 $^{4}$, 김영삼 ${ }^{* *}$ ${ }^{1}$ 상지영서대학교 뷰티케어과, 강원도 원주시, 한국

${ }^{2}$ 경인여자대학교 피부미용과, 인천, 한국

${ }^{3}$ 한라대학교 뷰티케어디자인학과, 강원도 원주시, 한국

${ }^{4}$ 건국대학교 화장품공학과 질병분자표적신약연구소, 서울, 한국

${ }^{5}$ 건국대학교 산업대학원 이미지산업학과, 서울, 한국

목적: 본 연구는 인간각질형성세포(HaCaT)에서 자외선(UV) 손상에 대한 항산화 및 항염증 효과를 확인하여 피부노화 예방 화장품 소재로서 sinapic acid의 가능성을 확인하고자 한다. 방법: Sinapic acid를 농도별로 HaCaT에 처리 후 UVB로 산화적 스트레스를 유도하였다. UVB에 대한 sinapic acid의 세포보호효과를 확인하기 위하여 water-soluble tetrazolium salt (WST-1)를 이용하였으 며, UVB에 의하여 생성된 활성산소종(reactive oxygen species, ROS)의 농도변화는 2,7-dichlorofluorescin diacetate (DCF-DA)를 사용하여 측정하였다. 항산화 및 염증과 관련된 유전자 발현은 quantitative real-time polymerase chain reaction (qRT-PCR)을 통 해 확인하였다. 결과: Sinapic acid는 UVB에 의한 세포독성으로부터 세포를 보호하고, ROS의 생성을 감소시킨다. 항산화와 관련 한 유전자인 superoxide dismutase 1 (SOD1), catalase (CAT), glutathione peroxidase 1 (GPX1), nuclear factor (erythroid-derived 2)-like 2 (NRF2) 및 heme oxygenase 1 (HO1)의 발현을 증가하게 하였고, 지질 과산화는 농도 의존적으로 감소하였다. 또한, 염증 과 관련이 있는 cyclooxygenase $2(C O X 2)$, interleukin 6 ( $\amalg 6)$ 와 interleukin 8 (IL)의 유전자 발현은 농도 의존적으로 감소하였다. 결론: 본 연구를 통하여 sinapic acid가 UVB에 대하여 항산화 및 항염증의 효과가 있음을 확인하였으며 이는 노화예방 화장품 성분 으로서의 가능성이 있을 것으로 사료된다.

핵심어: Sinapic acid, 항산화, 항염증, 자외선 B, 인간각질형성세포

본 논문은 보건복지부 보건의료연구개발사업의 지원(과제번호: $\mathrm{HN13C0080)에} \mathrm{의한} \mathrm{것이며,} \mathrm{이에} \mathrm{감사드립니다.}$

\section{참고문헌}

이민걸, 조광현, 김명남. 피부의 구조 및 기능. In: 피부과학. 대한피부과학회교과서편찬위원회(ed.), 여문각, 서울, pp1-29, 2001.

이나경, 구정은, 한효선. 인간진피섬유아세포에서 6-shogaol의 세포보호 및 항염증 효과. 아시안뷰티화장품학술지, 15: 367376, 2017. 


\section{中文摘要}

\section{芥子酸(Sinapic acid)对UVB诱导损伤的人角质形成细胞的抗氧化以及抗炎功效}

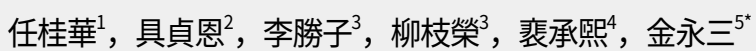

1劣志岭西大学美容学科, 江原道原州市, 韩国

2敬仁女子大学皮肤美容科, 仁川, 韩国

3汉拏大学美容设计学科, 江原道原州市, 韩国

${ }^{4}$ 建国大学化妆品工学科疾病分子靶标新药研究所, 首尔, 韩国

5 建国大学产业大学院影像产业学科, 首尔, 韩国

目的: 探讨芥子酸对UVB诱导损伤的人角质形成细胞的抗氧化以及抗炎功效, 确认芥子酸作为抗衰老化妆品原料的可 行性。方法: 对HaCaT细胞用不同浓度的芥子酸处理后, 利用UVB进行氧化应激。为确认芥子酸的细胞保护作用, 利用 water-soluble tetrazolium salt (WST-1)方法来评价; 为确认由UVB诱导产生的活性氧 (reactive oxygen species, ROS)的 浓度变化, 利用2',7'-dichlorofluorescin diacetate (DCF-DA)来进行测定; 为确认与抗氧化和抗炎相关的遗传因子的表达 程度, 利用quantitative real-time polymerase chain reaction (qRT-PCR)方法来测定。结果: 芥子酸由UVB产生的细胞 毒性中保护细胞，并减少ROS的生成。芥子酸增加与抗氧化相关的遗传因子superoxide dismutase 1 (SOD1)、catalase $(C A T)$ 、glutathione peroxidase 1 (GPX1)、nuclear factor (erythroid-derived 2)-like 2 (NRF2)以及heme oxygenase 1 $(H O 1)$ 等的表达程度, 并以浓度依赖性方式减少脂质过氧化。此外, 与炎症相关的遗传因子cyclooxygenase 2 (COX2)、 interleukin 6 (IL6)以及interleukin 8 (IL8)的表达以浓度依赖性方式减少。结论: 从以上的研究结果, 芥子酸对UVB具有抗 氧化和抗炎作用，因此作为预防衰老的化妆品原料充分具有可行性。

关键词: 芥子酸，抗氧化，抗炎，UVB，人角质形成细胞 